\title{
Neonatal Outcomes after Preconceptional Vaginal Micronized Progesterone Administration in Recurrent Pregnancy Loss: Five Years Prospective Study
}

\author{
${ }^{1}$ Manuela Russu, ${ }^{2}$ Ruxandra Stănculescu, ${ }^{3}$ Maria Păun, ${ }^{4}$ Jan Andi Marin
}

\section{ABSTRACT}

Objectives: The objective of this prospective study was to analyze the effect of vaginal micronized progesterone (VMP) daily administrated in women with recurrent pregnancy loss, recurrent miscarriage, and/or preterm birth on neonatal outcomes.

Methods: In the treat group patients received $200 \mathrm{mg} /$ day VMP (14 days/month, during the luteal phase) from preconception until completed 36 weeks of gestation. Women from the control group did not receive VPM treatment. Ultrasonographic examination was performed for gestational age confirmation, assessment of cervical length and congenital malformation screening in fetus.

Results: Compared with the control group, the women from the VMP group had a decreased time to conception, lower frequency of miscarriages and higher gestational age at delivery. Newborns from mothers treated with VPM had significantly higher birth weight than newborns from the control group of mothers $(p=0.022)$. The frequency of stillbirths and the need for oxygen supplementation and mechanical ventilation was lower in the newborns from treated group of mother compared with control group.

Conclusion: Vaginal micronized progesterone $200 \mathrm{mg} /$ day from preconception to 36 weeks of gestation in women with recurrent pregnancy loss reduced the frequency of miscarriages, stillbirths, preterm births and neonatal morbidity.

Keywords: Vaginal micronized progesterone, Preconception, Miscarriage, Prematurity.

How to cite this article: Russu M, Stănculescu R, Păun M, Marin JA. Neonatal Outcomes after Preconceptional Vaginal Micronized Progesterone Administration in Recurrent Pregnancy Loss: Five Years Prospective Study. Donald School J Ultrasound Obstet Gynecol 2014;8(2):128-133.

\footnotetext{
${ }^{1,2}$ Associate Professor and Head, ${ }^{3}$ Consultant, ${ }^{4}$ Specialist

${ }^{1,4} \mathrm{Dr}$ I Cantacuzino Clinic of Obstetrics and Gynecology, Carol Davila University of Medicine and Pharmacy, Bucharest, Romania

${ }^{2}$ St Pantelimon Clinic of Obstetrics and Gynecology, Carol Davila University of Medicine and Pharmacy, Bucharest, Romania

${ }^{3}$ Dr I Cantacuzino Clinic of Neonatology, Carol Davila University of Medicine and Pharmacy, Bucharest, Romania
}

Corresponding Author: Manuela Russu, Associate Professor and Head, Dr I Cantacuzino Clinic of Obstetrics and Gynecology, 5-7 I. Movilă Street, Bucharest 020475, Romania, Phone: +40-212102806 Fax: +40-212117062, e-mail: manuela_russu@yahoo.com

\section{Source of support: Nil}

Conflict of interest: None

\section{INTRODUCTION}

The growth and development of the conceptus (embryo/ fetus), and of the extra-embryonic membranes in mammals requires progesterone and placental hormones. These hormones regulate differentiation and function of endometrial stromal cells, uterine receptivity for blastocyst implantation, pregnancy recognition signaling and interactions between the maternal and fetal DNA. ${ }^{1}$ Additionally, these hormones are involved in the embryo protection from malformations and rejection, ${ }^{2,3}$ its growth, development, and prevention of preterm birth.

In the last 40 to 50 years, progestins and progesterone derivatives have been used during reproductive age for support of luteal phase when luteal phase defect or inadequate corpus luteum were present. Prostins and progesterones were also used for spontaneous pregnancy achievement or in vitro fertilization treatment; ${ }^{4,5}$ prevention of miscarriages, ${ }^{6}$ preterm labor ${ }^{7}$ and recurrent pregnancy loss. ${ }^{8}$ Progesterone is used as a support for pregnancy in women with short cervix, ${ }^{9-11}$ and as monotherapy for primary prevention of preterm birth, ${ }^{12,13}$ with a good cost-effective ratio. ${ }^{14}$

\section{PATIENTS AND METHODS}

The objective of this prospective study was to analyze the effect of daily administration of $200 \mathrm{mg}$ vaginal micronized progesterone (VMP) from preconception to complete 36 weeks of gestation in women with recurrent pregnancy loss, recurrent miscarriage, and/or preterm birth on neonatal outcome.

This was a prospective controlled study conducted from January 2007 to December 2011 with the following inclusion criteria; pregnant women with a history of at least two miscarriages or at least a preterm birth at 26 to 37 weeks, and cervical length at enrollment $\geq 20 \mathrm{~mm}$. Exclusion criteria were as follows: pregnant women with major uterine malformations, infection with toxoplasma, listeria, cytomegalovirus or syphilis; chronic diseases (e.g. insulin treated diabetes mellitus, hypertension, treatment with 
unfractioned or low molecular weight heparins, coagulopathies or platelet disorders); previous pregnancies with chromosomal abnormalities (numerical, aneuploidies, or structural chromosomal defects); previous pregnancy with duration over 42 weeks with stillborn fetus. All treated patients signed an informed consent before enrollment and before conception.

There were two study groups: the treatment group and the control group. In the treatment group patients received $200 \mathrm{mg} /$ day VMP (14 days/month, during the luteal phase) from preconception until completed 36 weeks of gestation. Women from the control group did not receive VPM treatment. When considered necessary, the treating physician offered a nonspecific muscle-relaxant mixture.

Ultrasonographic examination was performed at 16 to 23 weeks and 6 days of gestation for gestational age confirmation, assessment of cervical length and screening for congenital malformations. This examination was repeated at 32 to 34 weeks of gestation for assessment of fetal development and maturation.

The primary outcomes were time until conception $(<6$ months, $>6$ months), evaluation of gestational age (GA) at miscarriage, GA at delivery, GA at birth according to the cervical length at 16 to 23 weeks and 6 days, birth weight, Apgar scores, the presence of congenital malformations and neonatal morbidity including severe respiratory distress syndrome, bronchopulmonary dysplasia, intraventricular hemorrhage and necrotizing enterocolitis. The secondary outcomes were the frequency of stillbirths, fetal deaths before discharge, oxygen supplementation, mechanical ventilation and the length of stay at Neonatal Intensive Care Unit.

\section{Statistical Analysis}

The treatment groups were compared using the student t-test and ANOVA procedure. A p-value $<0.01$ was considered statistically significant.

\section{RESULTS}

Seven hundred and forty treated patients and 660 controls with similar mean age were included in this analysis (Table 1). Six hundred and forty-eight (84.2\%) of the treated women and $390(60.7 \%)$ of the women in the control group had a time between study enrollment and conception of $<6$ months. One hundred and seventy $(21.9 \%)$ women from the treatment group and $154(23.4 \%)$ from the control group presented a miscarriage during the first 12 weeks of gestation. Between 16 and 24 weeks of gestation women from the treatment group reported statistically significant fewer miscarriages than the women from the control group: $70(7.2 \%)$ vs $60(9.3 \%) ; \mathrm{p}<0.001$. The mean gestational age at delivery was $38.27 \pm 1.61$ weeks in the treatment group and $35.09 \pm 3.05$ weeks in the control group, $\mathrm{p}<0.001$. Ten $(1.3 \%)$ women from the treatment group and $29(4.8 \%)$ from the control group delivered between 24 and 28 weeks of gestation; $34(5.3 \%)$ women from the treatment group and $250(39 \%)$ from the control group delivered between 29 and 34 weeks of gestation; 386 (93.4\%) women from the treatment group and $167(56.2 \%)$ women from the control group delivered $\geq 35$ weeks. The gestational age at delivery according to the cervical length measured at 16 to 23 weeks and 6 days is presented in Table 2 .

Newborns from VPM treated mothers had a significantly higher birth weight than newborns from untreated mothers

Table 1: Maternal characteristics

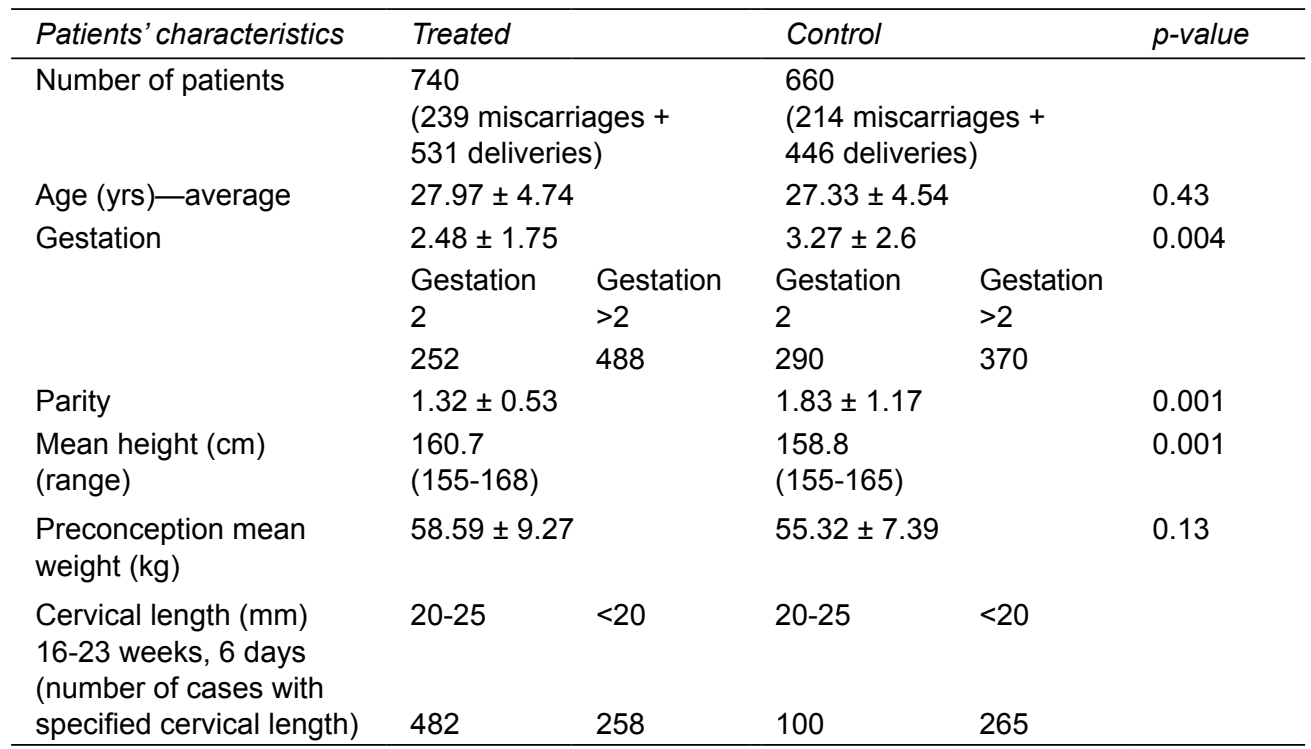


Table 2: Gestational age at delivery by cervical length

\begin{tabular}{|c|c|c|c|c|}
\hline \multirow[t]{2}{*}{$\begin{array}{l}\text { Gestational age } \\
\text { at delivery }\end{array}$} & \multicolumn{2}{|c|}{$\begin{array}{c}\text { Treated } \\
\text { (239 miscarriages }+531 \text { deliveries })\end{array}$} & \multicolumn{2}{|c|}{$\begin{array}{c}\text { Control } \\
\text { (214 miscarriages }+446 \text { deliveries) }\end{array}$} \\
\hline & $11-25 \mathrm{~mm}$ & $<10 \mathrm{~mm}$ & $11-25 \mathrm{~mm}$ & $<10 \mathrm{~mm}$ \\
\hline 24-28 weeks & 0 & 10 & - & 29 \\
\hline 29-34 weeks & 11 & 23 & - & 250 \\
\hline 35-36 weeks, 6 days & 6 & 30 & - & 25 \\
\hline
\end{tabular}

Table 3: Infants' primary outcomes

\begin{tabular}{|c|c|c|c|c|c|c|c|c|c|c|c|}
\hline \multicolumn{2}{|c|}{ Infants' outcome } & \multicolumn{5}{|c|}{$\begin{array}{l}\text { Treated ( } 239 \text { miscarriages + } \\
531 \text { deliveries) }\end{array}$} & \multicolumn{3}{|c|}{$\begin{array}{l}\text { Control ( } 214 \text { miscarriages + } \\
446 \text { deliveries) }\end{array}$} & \multicolumn{2}{|l|}{$p$-value } \\
\hline \multicolumn{2}{|c|}{ Fetal weight (gm) } & \multicolumn{5}{|c|}{$3227 \pm 556$} & \multicolumn{3}{|c|}{$2457 \pm 601$} & \multicolumn{2}{|l|}{0.022} \\
\hline \multicolumn{2}{|c|}{$\begin{array}{l}\text { Fetal weight (gm) } \\
\mathrm{N}\end{array}$} & \multicolumn{3}{|c|}{$\begin{array}{l}<1500 \\
5\end{array}$} & \multicolumn{2}{|c|}{$\begin{array}{l}<2500 \\
30\end{array}$} & \multicolumn{2}{|l|}{$\begin{array}{l}<1500 \\
20\end{array}$} & $\begin{array}{l}<2500 \\
80\end{array}$ & \multicolumn{2}{|l|}{0.0001} \\
\hline \multicolumn{12}{|c|}{ Apgar score } \\
\hline \multicolumn{2}{|l|}{ - 1 minute } & \multirow{2}{*}{\multicolumn{5}{|c|}{$\begin{array}{l}8.45 \pm 1.53 \\
8.77 \pm 1.11\end{array}$}} & \multirow{2}{*}{\multicolumn{3}{|c|}{$\begin{array}{l}8.05 \pm 1.98 \\
8.20 \pm 1.99\end{array}$}} & \multirow{2}{*}{\multicolumn{2}{|c|}{$\begin{array}{l}0.40 \\
0.21\end{array}$}} \\
\hline - 5 minutes & & & & & & & & & & & \\
\hline $\begin{array}{l}\text { Apgar sco } \\
<7 \text { at } 5 \mathrm{mi}\end{array}$ & $\begin{array}{l}\text { e } \\
\text { utes }\end{array}$ & \multicolumn{5}{|c|}{$55(7.4 \%)$} & \multicolumn{3}{|c|}{$85(12.9 \%)$} & \multicolumn{2}{|l|}{$<0.001$} \\
\hline \multirow{2}{*}{\multicolumn{2}{|c|}{$\begin{array}{l}\mathrm{pH} \text { blood cord } \\
\text { when Apgar } \\
<7 \text { at } 5 \text { minutes }\end{array}$}} & \multicolumn{2}{|c|}{$<7.20$} & \multicolumn{2}{|c|}{$7.21-7.24$} & $>7.25$ & $<7.20$ & $\begin{array}{l}7.21- \\
7.24\end{array}$ & $>7.25$ & & \\
\hline & & \multicolumn{2}{|l|}{12} & \multicolumn{2}{|l|}{0} & 43 & 24 & 5 & 56 & & \\
\hline \multicolumn{2}{|c|}{ Malformations } & \multicolumn{8}{|c|}{$\begin{array}{l}\text { Hypospadias: } 10 \text { in each group } \\
\text { Criptorhidia: } 5 \text { in control } \\
\text { Hydrocele: } 3 \text { in control } \\
\text { Umbilical hernia: } 2 \text { in control } \\
\text { Talus var: } 5 \text { in control } \\
\end{array}$} & & \\
\hline \multicolumn{12}{|c|}{ Composite neonatal morbidity } \\
\hline \multicolumn{3}{|c|}{$R D S$} & \multicolumn{4}{|c|}{$B P D$} & \multicolumn{3}{|c|}{$\mathrm{IVH}$} & \multicolumn{2}{|c|}{ NEC } \\
\hline A & \multicolumn{2}{|l|}{$\mathrm{B}$} & \multicolumn{2}{|l|}{ A } & B & & A & $\mathrm{B}$ & & A & $\mathrm{B}$ \\
\hline $15(2.7 \%)$ & $25(3.7$ & $8 \%)$ & 2( & $27 \%)$ & $4(0$ & $0 \%)$ & 0 & $1(C$ & $.15 \%)$ & $2(0.27 \%)$ & $5(0.75 \%)$ \\
\hline
\end{tabular}

$(\mathrm{p}=0.022)$. Number of newborns from treated mothers with Apgar score $<7$ at 5 minutes was significantly lower that the number of newborns from untreated mothers $(\mathrm{p}>0.001)$ (Table 3$)$.

The frequency of stillbirths and the need for oxygen supplementation and mechanical ventilation were lower in the newborns from treated mother compared with those from untreated mothers (Table 4). The frequency of fetal death before discharge was similar in the two groups: 1.08 and $1.5 \%$ in the newborns from treated and untreated mothers respectively.

\section{DISCUSSION}

As many eastern European countries, Romania has experienced a decline of the population with a negative population growth rate in 2007 . The early neonatal mortality remained high compared with mortality rates at European level (6.09 vs 3.75/1,000 live births in Europe in 2005) but the infant mortality rate declined from 17.3 in 2002 to 9.2 deaths/1,000 live births in $2010 .{ }^{15}$ In this context, the healthcare professionals have the very important task of improving pregnancy outcomes.

The use of progesterone derivatives and progestins for reproduction has been discussed in the last 40 to 50 years. Currently, two types of progesterone formulations considered safe are available: natural progesterone with either oral or vaginal administration, and a semi-synthetic progesterone derivative only with oral administration.

Vaginal route is associated with a higher bioavailability of progesterone in the uterus (10 fold higher than after the oral administration), and minimal systemic undesirable effects. ${ }^{16-19}$ This higher bioavailability can be explained by the first uterine pass effect: direct diffusion through tissue, intracervical aspiration, absorption into the venous or lymphatic circulatory systems, and countercurrent vascular exchange with diffusion from uterovaginal veins and lymph vessels to arteries.

In our study, maternal age in treated patients was higher than in controls $(27.97 \pm 4.74$ vs $27.33 \pm 4.54 ; \mathrm{p}=0.43)$. 
Table 4: Infants' secondary outcomes

\begin{tabular}{|c|c|c|c|c|}
\hline Infants' outcome & \multicolumn{2}{|c|}{$\begin{array}{l}\text { Treated } \\
\text { (239 miscarriages + } \\
531 \text { deliveries) }\end{array}$} & \multicolumn{2}{|c|}{$\begin{array}{l}\text { Control } \\
\text { ( } 214 \text { miscarriages }+ \\
446 \text { deliveries) }\end{array}$} \\
\hline Stillbirth & \multicolumn{2}{|c|}{$20(2.63 \%)$} & \multicolumn{2}{|l|}{$33(5 \%)$} \\
\hline Fetal deaths before discharge & \multicolumn{2}{|c|}{$8(1.08 \%)$} & \multicolumn{2}{|l|}{$10(1.5 \%)$} \\
\hline Need of oxygen supplementation & \multicolumn{2}{|c|}{$104(13.4 \%)$} & \multicolumn{2}{|c|}{$440(61.2 \%)$} \\
\hline Mechanical ventilation & \multicolumn{2}{|c|}{$75(10.7 \%)$} & \multicolumn{2}{|c|}{$225(12.1 \%)$} \\
\hline \multirow{2}{*}{$\begin{array}{l}\text { Length of admission in the NICU } \\
\text { (total number of days) }\end{array}$} & $<7$ days & $>7$ days & $<7$ days & $>7$ days \\
\hline & - & $3(4.5 \%)$ & $5(12.1 \%)$ & $5(12.1 \%)$ \\
\hline
\end{tabular}

It was shown that the level of proinflammatory cytokines, reactive oxygen species, steroids and inducible nitric oxide synthase linked to apoptosis of corpus luteum increase with age. ${ }^{20}$ These cytokines and hormones induce a decrease of progesterone biosynthesis in mid and late luteal cells. ${ }^{20}$

Preconception progesterone supplementation increases the number of natural killer (uNK) cells CD $56^{\text {bright }} \mathrm{CD} 16^{\mathrm{dim}}$ in the pre-decidualized endometrium during luteal phase. ${ }^{21}$ These $\mathrm{uNK}$, that are $\beta$-hCG dependent from early moments of pregnancy, are phenotypically distinct from circulating peripheral $\mathrm{CD} 56^{\mathrm{dim}} \mathrm{CD} 16^{\text {bright }}$ and their number increases during pregnancy, contributing to a normal pregnancy and fetal development. ${ }^{22}$ Additionally, progesterone increases local production of Th2 and/or Leukemia Inhibiting Factor (LIF) cytokines which may contribute to the maintenance of pregnancy. The defective decidual production of LIF, M-CSF, Il -4, IL-10 and/or Th2 cytokines may be associated with unexplained recurrent abortions. ${ }^{23-25}$

Preconception progesterone supplementation modulates the contractility of fallopian tubes and myometrium for gamete/embryo transport throughout the uterotubal cavities and successful embryo implantation in spontaneous and/or assisted reproduction ${ }^{26-31}$ and maintains the viability of the decidua. ${ }^{32}$ Together with estrogens it decreases the vascular resistance in the uterine circulation and increases the rates of embryo implantation. These effects are mediated through its action on the endometrial stroma cells and on different cytokine profiles secreted in response to the paternal MHC histocompatibility antigens (the uterus is an immuneprivileged site during pregnancy).

Taking into account the mechanism underlying human parturition initiation 'progesterone functional withdrawal ${ }^{33-36}$ and because progestins/progesterone derivatives suppress Thrombin- and Il-1(beta)-induced interleukin 11 activities related to preterm delivery, the progesterone supplementation for prevention of preterm birth, ${ }^{5}$ abruptio placentae and chorioamnionitis ${ }^{37}$ is widely accepted.

Progesterone supplementation can be administered in different doses (from $90 \mathrm{mg} / \mathrm{day}$ to $200 \mathrm{mg} / \mathrm{day}^{38-40}$ ), according to medical history ${ }^{40-42}$ and treatment duration. ${ }^{40-43}$
We believe that a pregnancy should continue at least up to 37 complete weeks of gestation, because each week reduces neonatal risk. It was shown that VMP administration from preconception up to complete 36 weeks of gestation reduced the delivery rates before 37 weeks $(\mathrm{p}<0.01)$.

Recently the cervical length has been used as an parameter indicating the risk for late miscarriage or early preterm birth. ${ }^{9-11,44}$ We analyzed the VMP effect on pregnancy prolongation according to cervical length (below $10 \mathrm{~mm}$ or more) at 16 to 24 weeks gestation and we showed that in cases with known risk of recurrent preterm delivery progesterone supplementation early during the pregnancy, before the cervix becomes shorter, decreases the frequency of delivery before 36 weeks of gestation. Our results are in line with those previously reported. ${ }^{44}$

A meta-analysis of 2611 randomized clinical trials ${ }^{45}$ in asymptomatic women with a sonographic short cervix in the mid trimester of singleton and twin pregnancies, showed the efficacy and safety of vaginal progesterone for the prevention of preterm birth.

\section{CONCLUSION}

Vaginal micronized progesterone administered from preconception to 36 weeks of gestation in women with history of pregnancy loss and shortened cervix the frequency of miscarriages and preterm births and increases the gestational age at delivery. Additionally in newborns, its administration was associated with higher birth weight, lower number of cases with low umbilical cord $\mathrm{pH}$ at birth when Apgar score was $<7$ at 5 minutes and with a reduction of neonatal morbidity and mortality.

\section{ACKNOWLEDGMENTS}

Authors wish to acknowledge the editorial support provided by Adriana Rusu (XPE Pharma and Science).

\section{REFERENCES}

1. Romero R, et al. DNA variants of maternal and fetal genes may be linked to preterm birth. Abstract 14. The 30th Annual Meeting of the American Society for Maternal-Fetal Medicine: The Pregnancy Meeting 2010. 
2. Carp H, Torchinsky A, Fein A, Toder V. Hormones, cytokines and fetal anomalies in habitual abortion. Gynecol Endocrinol 2001;15:472-483.

3. Sekeres-Bartho J, Halasz M, Palkovics T. Progesterone in pregnancy; receptor-ligand interaction and signaling pathways. J Reprod Immunol 2009;83:60-64.

4. Daya S, Gunby J. Luteal phase support for assisted reproduction cycles. Cochrane Database Syst Rev 2004;3:CD004830.

5. Vander Linden M, Buckingham K, Farquhar C, Kremer JA, Metwally M. Luteal phase support for assisted reproduction cycles. Cochrane Database Syst Rev 2011;10:CD009154.

6. Wahabi H, Abed Althagafi N, Elawad M. Progestogen for treating threatened miscarriage. Cochrane Database Syst Rev 2007; 3:CD005943.

7. Dodd JM, Flenady V, Cincotta R, Crowther CA. Prenatal administration of progesterone for preventing preterm birth. Cochrane Database Syst Rev 2006;1:CD004947.

8. Russu M, Stănculescu R, Nastasia Ş, et al. Neonatal Outcomes after preconceptional vaginal micronized progesterone administration in recurrent pregnancy loss. Abstract, CDCBudapest, Hungary, Ist Central and Eastern European Summit on Preconceptional Medicine and Prevention of Birth Defects. 2008 Aug:27-30.

9. Cahill AG, Odibo AO, Caughey AB, et al. Universal cervical length screening and treatment with vaginal progesterone to prevent preterm birth: a decision and economic analysis. Amer J Obstet Gynecol 2010;202 (6):548.

10. Campbell S. Universal cervical-length screening and vaginal progesterone prevents early preterm births, reduces neonatal morbidity and is cost saving: doing nothing is no longer an option. Ultrasound Obstet Gynecol 2011;38:1-9.

11. Werner EF, Han CS, Pettker CM, et al. Universal cervical-length screening to prevent preterm birth: a cost-effectiveness analysis. Ultrasound Obstet Gynecol 2011;38:32-37.

12. Ballas J. Population-based risk scoring can effectively predict preterm birth risks earlier than cervical length screening followed by fetal fibronectin testing. American Congress of Obstetricians and Gynecologists' Annual Clinical Meeting, 2012.

13. Society for Maternal-Fetal Medicine Publications Committee, with assistance of Vincenzo Berghella. Progesterone and preterm birth prevention: translating clinical trials data into clinical practice. Am J Obstet Gynecol 2012;206:376-386.

14. Kowalski JT. A guide to the cost of progesterone for prevention of preterm labor. Proc Obstet Gynecol 2011 April;1(3):9.

15. Romanian National Statistical Institute. Available at: http://www. insse.ro/cms/.

16. Miles RA, Paulson RJ, Lobo RA, Press MF, Dahmoush L, Sauer MV. Pharmacokinetics and endometrial tissue levels of progesterone after administration by intramuscular and vaginal routes: a comparative study. Fertil Steril 1994;62:485-490.

17. Cicinelli E, de Ziegler D. New hypotheses transvaginal progesterone: evidence for a new functional 'portal system' flowing from the vagina to the uterus. Hum Reprod Update 1999;5:365-372.

18. Einer-Jensen N, Ciccinelli E, Galantino P, et al. Preferential vascular-based transfer from vagina to the corpus but not to the tubal part of the uterus in postmenopausal women. Hum Reprod 2001;16;1329-1333.

19. Cicinelli E. Intravaginal estrogen and progestin administration: advantages and disadvantages. Best Pract Res Clin Obstet Gynaecol 2008;22:391-405.
20. Devoto L, Vega M, Kohen P, et al. Molecular regulation of progesterone secretion by the human corpus luteum throught the menstrual cycle. J Reprod Immunol 2002;55:11-20.

21. Kalkunte S, Chichester CO, Gotsch F, et al. Evolution of noncytotoxic uterine natural killer cells. Am J Reprod Immunol 2008;59:425-432.

22. Kane N, Kelly R, Saunders TKP, Critchhley ODH. Proliferation of uterine natural killer cells is induced by $\mathrm{hCG}$ and mediated via the mannose receptors. Endocrinology 2009;150:2882-2888.

23. Piccinni M, Beloni L, Livi C, et al. Defective production of both leukemia inhibitory factor and type 2T-helper cytokines by decidual $\mathrm{T}$ cells in unexplained recurrent abortions. Nat Med 1998;4:1020-1024.

24. Piccinni M, Maggi E, Romagnani S. Role of hormone-controlled T-cell cytokines in the maintenance of pregnancy. Biochem Soc Trans 2000;28:212-215.

25. Piccinni M, Scaletti C, Vultaggio A, Romagnani S, Romagnani S. Defective production of LIF, M-CSF and Th2-type cytokines by $\mathrm{T}$ cells at fetomaternal interface is associated with pregnancy loss. J Reprod Immunol 2001;52:35-43.

26. Goldenberg RL, Iams JD, Mercer BM, et al. The preterm prediction study: the value of new vs standard risk factors in predicting early and all spontaneous preterm births. Am J Public Health 1998;88:233-238.

27. Ayoubi JM, Fanchin R, Kaddouz D, Frydman R, de Ziegler D. Uterorelaxing effects of vaginal progesterone: comparison of two methodologies for assessing uterine contraction frequency on ultrasound scans. Fertil Steril 2001;76:736-740.

28. Bulleti C, de Ziegler D, Setti PL, Cicinelli E, Polli V, Flamigni C. The patterns of uterine contractility in normal menstruating women: from physiology to pathology. Ann NY Acad Sci 2004;1034:64-83.

29. Palagiano A, Bulletti C, Pace MC, DE Ziegler D, Cicinelli E, Izzo A. Effects of vaginal progesterone on pain and uterine contractility in patients with threatened abortion before 12 weeks of pregnancy. Ann NY Acad Sci 2004;1034:200-210.

30. Manno M, Marchesan E, Cicutto D, Zadro D, Favretti C, Tomei E. Greater implantation and pregnancy rates with vaginal progesterone in intracytoplasmic sperm injection but not in in vitro fertilization cycles: a retrospective study. Fertil Steril 2005;83:1391-1396.

31. Bulletti C, de Ziegler D. Uterine contractility and embryoimplantation. Curr Opin Obstet Gynecol 2006;18:473-484.

32. Lan KKG, DeMets DL. Discrete sequential boundaries for clinical trials. Biometrika 1983;70:659-663.

33. Henderson D, Wilson T. Reduced binding of progesterone receptor to its nuclear response element after human labor onset. Am J Obstet Gynecol 2001;185:579-585.

34. Brown GA, Leite SR, Strauss JF 3rd. Mechanisms underlying 'functional' progesterone withdrawal at parturition. Ann NY Acad Sci 2004;1034:36-49.

35. Taylor HA, McParland CP, Taylor JD, Bell CS. The cytoplasmic $60 \mathrm{kDa}$ progesterone receptor isoform predominates in the human amniochorion and placenta at term. Reprod Biol Endocrinol 2009;7:22.

36. Csapo A. The luteo-placental shift, the guardian of prenatal life. Postgrad Med J 1969;45:57-64.

37. Cakmak H, Schatz F, Huang S-TJ, et al. Progestin suppresses thrombin and Il-1beta-Induced Interleukin 11. J Clin Endocrinol Metab 2005;90:5279-5286.

38. O'Brien JM, Adair CD, Lewis DF, et al. Progesterone vaginal gel for the reduction of recurrent preterm birth: primary results from 
a randomized, double-blind, placebo-controlled trial. Ultrasound Obstet Gynecol 2007;30:687-696.

39. da Fonseca EB, Bittar RE, Carvalho MH, Zugaib M. Prophylactic administration of progesterone by vaginal suppository to reduce the incidence of spontaneous preterm birth in women at increased risk: a randomized placebo-controlled double-blind study. Am J Obstet Gynecol 2003;188:419-424.

40. da Fonseca EB, Celik E, Singh M, Nicolaides KH, et al. Progesterone and the risk of preterm birth among women with a short cervix. N Engl J Med 2007;357:462-469.

41. Meis PJ, Klebanoff M, Thom E, et al. Prevention of recurrent preterm delivery by 17 alpha- hydroxyprogesterone caproate. $\mathrm{N}$ Engl J Med 2003;348:2379-2385.
42. Hoyert DL, Mathews TJ, Menacker F, Strobino DM, Guyer B. Annual summary of vital statistics: Pediatrics 2004;117: 168-183.

43. Angelini D. Late preterm birth: Beware! Journal Watch Women's Health 2008.

44. Hassan SS, Romero R, Maymon E, et al. Does cervical cerclage prevent preterm delivery in patients with a short cervix? Am J Obstet Gynecol 2001;184:1325-1329.

45. Romero R, Nicolaides K, Conde-Agudelo A, et al. Vaginal progesterone in women with an asymptomatic sonographic short cervix in the midtrimester decreases preterm delivery and neonatal morbidity: a systematic review and meta-analysis of individual patient data. Am J Obstet Gynecol 2012;206:124. 